\title{
Studies on Twin Micro-Watersheds, Melekote and Rajagatta Dodballapur Taluk, Bangalore Rural District, Karnataka State through Morphometry, Land Formation and Water Quality
}

\author{
S. G. Ramachandraiah ${ }^{1}$, M. Inayathulla ${ }^{2}$, P. S. Nagaraj ${ }^{2}$, G. Ranganna ${ }^{3}$, R. Druvashree ${ }^{4}$ \\ ${ }^{1}$ Faculty in Civil Engineering, Dr. Ambedkar Institute of Technology, Bangalore, India \\ ${ }^{2}$ Faculty in Civil Engineering, University Visvesvaraya College of Engineering, Bangalore, India \\ ${ }^{3}$ UGC-CAS in Fluid Mechanics, Bangalore University, Bangalore, India \\ ${ }^{4}$ University of Agricultural Sciences, Bangalore, India \\ Email: sgr_dl@yahoo.co.in
}

Received September 28, 2012; revised November 1, 2012; accepted November 10, 2012

\begin{abstract}
The paper discusses assessment of various chemical constituents present in groundwater besides morphology, and land form characteristics of twin micro-watersheds (viz., Melekote and Rajaghatta) Dodballapur Taluk, (Karnataka) coming under semi-arid climatic zone. Farmers who are mainly depending on agricultural yields for their living are disappointed due to vagaries of monsoons and undependable rainfall. This is particularly so in arid and semi-arid regions. These regions suffer from water scarcity, soil degradation, low crop yield, high soil erosion and gradual depletion of soil fertility. All these factors culminate in planning for conservation and storage of water in small watersheds for future needs, i.e., during drought conditions. In many areas, it is observed that the water table levels are declining resulting in problems of increased concentration of solutes and deterioration of groundwater quality. All aspects of hydrological studies are covered in relation to watershed management in order to formulate strategies for sustainable agricultural development. Morphometry, landform and topography play an important role in understanding the hydrological response of any watershed. Quantitative morphometric analysis has been carried out on the watershed along with landform and topographical study.
\end{abstract}

Keywords: Water Quality; Morphometry; Groundwater; Land Form

\section{Introduction}

The behavior of any watershed depends on interactions between the flow of matter and energy moving within limits and resistance to topographical surface [1]. There is need to bring together science, engineering, social sciences and humanities to achieve the goal of equitable water management. Here, our work concentrates on field-cum-office work concerning twin micro-watersheds falling within Arkavati river basin which originates from the foothills of Nandi hills. An attempt is also made to suggest steps to carry out economic management of available water, taking into consideration parameters of hydrology, soils and water. The rapid growth in water demand is due to the increasing reliance on irrigation to offset food security and increasing use for domestic purposes. Irrigated agriculture takes about 70 percent of water withdrawals and the figure rises to 90 percent in the dry tropics. This generally has low water use efficiency.
The interrelation between morphometric parameters, landform and topography governs the existence and response of watershed to the surface as well as ground water movement [2]. Groundwater is an integral part of the hydrologic cycle. Ground water often consists of seven major chemical constituents namely: $\mathrm{Ca}^{2+}, \mathrm{Mg}^{2+}, \mathrm{Cl}^{-}$, $\mathrm{HCO}_{3}^{-}, \mathrm{Na}^{+}, \mathrm{K}^{+}$and $\mathrm{SO}_{4}^{2-}$. The chemical parameters of groundwater play a significant role in classifying and assessing the water quality. Considering the individual and paired ionic concentration, certain indices are proposed to determine the alkali hazards. Residual sodium carbonate (RSC) can be used as a criterion for finding the suitability of irrigation waters. Ten tiny dams with a catchment of 1 ha each will collect much more water than a larger dam with a catchment of 10 ha [3]. Several studies conducted in India also show a clear relationship between the size of catchment and amount of runoff that can be captured [4]. The two watersheds fall within the geographical boundary of Dodballapur taluk (792 sq km), 
one of the four taluks in Bangalore rural district.

\section{General Features of the Study Area}

Twin watersheds come under the confluence of Kumudavathy river catchment, a tributary to river Arkavati joining Cauvery river (Sangama, Kanakapura taluk, Ramanagaram District) downstream. Figure 1 shows Melekote and Rajaghatta together cover an area of 98.5 $\mathrm{km}^{2}$. They fall between $13^{\circ} 07^{\prime} 41^{\prime \prime}$ and $13^{\circ} 23^{\prime} 15^{\prime \prime}$ north latitude and $77^{\circ} 34^{\prime} 24^{\prime \prime}$ and $77^{\circ} 40^{\prime} 20^{\prime \prime}$ east longitude. Dodballapur taluk lies in the semi-arid region, receiving $796 \mathrm{~mm}$ of rainfall annually in 58 rainy days. Both the catchments receive rainfall from south-west monsoon and the humidity will not exceed $50 \%$. The entire taluk suffers from scarcity of water, uncontrolled sand mining and natural resource degradation.

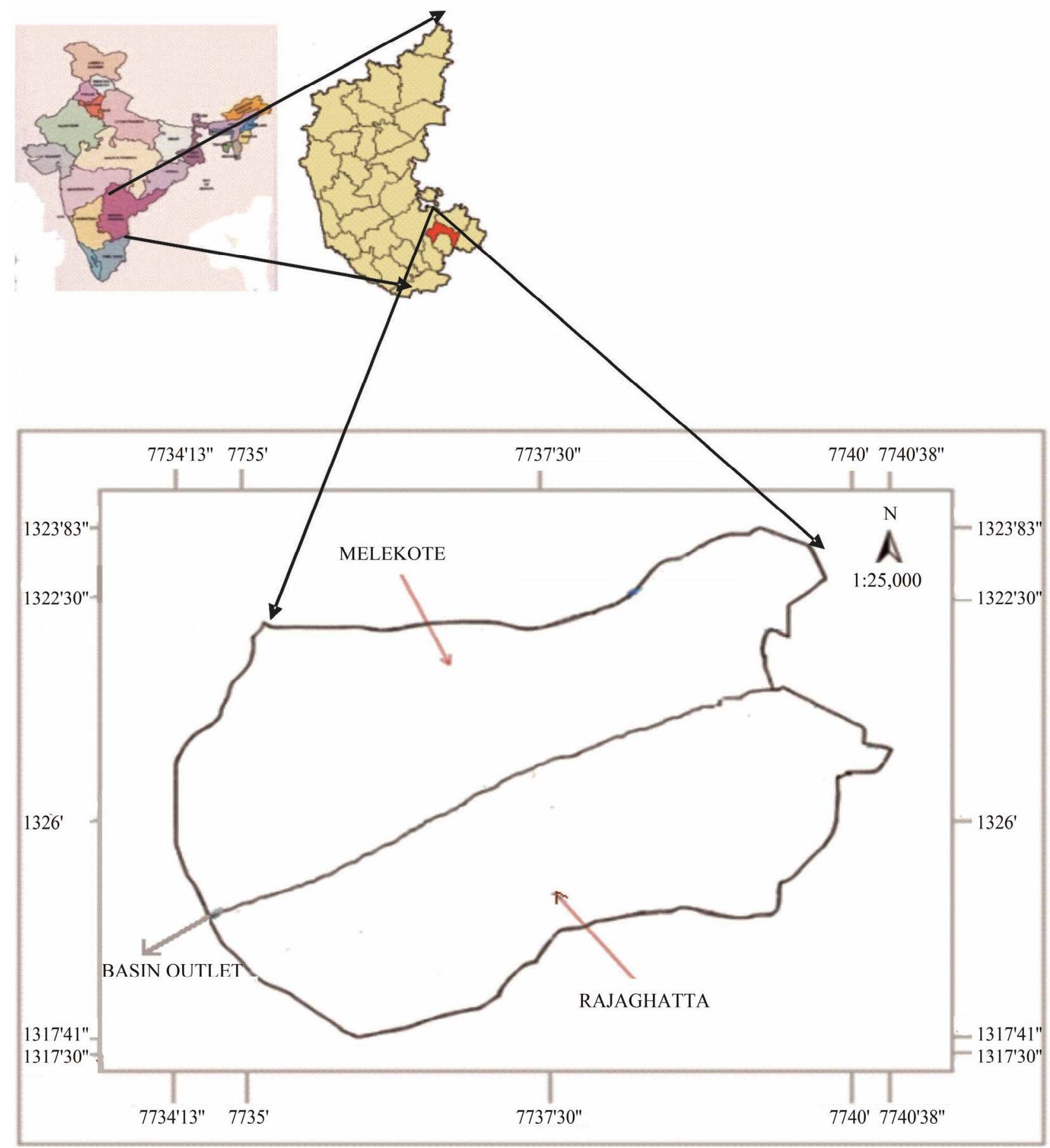

Figure 1. Sub-watersheds. 


\section{Methodology}

Quantitative analysis of morphometric parameters of the watershed enables 1) derivation of relationship between drainage patterns of the same watershed; 2) comparative studies of different watersheds developed in different environs and 3) identification of certain useful parameters of watersheds in numerical terms [5]. Within the boundary of twin watersheds the following are details of the field work carried out for water quality studies in Melekote -8 wells. Besides in Rajaghatta another 8 wells are explored for water quality, during three successive seasons, viz., Pre-monsoon, monsoon and post monsoon periods. The collected water samples were transferred into precleaned polythene containers for analysis of chemical characteristics. Chemical analyses were carried out for the major ion concentrations of the water samples collected from different locations using standard procedures as recommended by APHA-1994. The data can be used for classification of water for different utility purposes and for ascertaining various factors on which the chemical characteristics of water depend.

\section{Hydrogeology}

Occurrence, movement and storage of groundwater is influenced by lithology, thickness and structure of rock formations. Laterites overlying peninsular gneisses also form good aquifers. Groundwater in the district occurs in weathered crystalline rocks under unconfined conditions and in fractured rocks under semiconfined conditions. Large diameter shallow dug wells are the main groundwater structures. Due to increased demand for water most of the dug wells have dried up although some of them are revitalized by drilling bores at the bottom of the dug wells (Dug-cum-bore wells). General water table level has also fallen. Static water levels are recorded in the observation wells by the Dept. of Mines and Geology, GoK. By utilizing the data on water levels in the observation wells, fluctuation of water table can be predicted, i.e., fluctuation varied from $0-55 \mathrm{~m}$ to $11.83 \mathrm{~m}$ below ground level.

\section{Landform and Morphometric Analysis}

Morphometric parameters of the study area have been determined for the two twin watersheds in addition to general characteristics of the watersheds. The catchment area consists of dykes, lineaments and water bodies. The watersheds, form a gently sloping rolling topography with the slope from north to south amounting to $2.5 \%$. There are 52 villages inside the catchment boundary and the population is 45,928 The entire population depends upon groundwater for domestic needs. The area consists of one of the oldest rock formations of Archaen age.
Peninsular gneisses cover a large portion of Bangalore district. They are highly migmatitic in nature. Their composition is of granodioritic material. Gneisses are generally grey in color. They are jointed with sheet joints almost parallel to the ground surface. The granites are medium to coarse grained, and equigranular in texture. Dykes are oriented east west as well as north south. The study area has red loamy soils and they are fairly well drained. Slopes range from 1 to 3 percent, slightly moderately eroded. The major land use classification is agriculture (95\%) and forests (2\%) and the alluvial deposits are noticed over a small area. Infiltration rates range from 8 to $12 \mathrm{~mm} /$ hour. Geomorphologically we find residual hills of granites and charnockites with varying elevations, aerial extent and dissection. Pediplains are also found with gently undulating with fairly thick weathered mantle over granites and gneisses. Pediplains are also found with gently undulating with fairly thick weathered mantle over granites and gneisses. Quantitative analysis of morphimetric parameters is done for the watershed considered for study. The parameters so estimated are presented in Table 1. The adjoining watersheds have developed $3^{\text {rd }}$ order streams indicating similar level of maturity attained. The watersheds area and perimeter for combined Melekote and Rajaghatta is 95.83 sq $\mathrm{km}$ and $43.62 \mathrm{~km}$. The elevation of the Melekote is $968 \mathrm{~m}$ and Rajaghatta $911 \mathrm{~m}$ above msl. The watersheds relief ratio is less 0.017 resulting in low relief. The stream ranking is done on Strahlers [6] system. Table 2 shows that the total number of stream segments of a particular order are smaller in number than for the immediate lower order but larger in number of segments than for the next higher order. Figure 2 supports the Strahlers law. This relation leads to the definition of bifurcation ratio. Table 1 also shows bifurcation ratio for both the watersheds. The average bifurcation ratio obtained for watershed is 3.6. The bifurcation ratio is indicative of mild slope in the watersheds. Figure 3 the mean stream of a stream channel segment of certain order is a dimension property, which reveals the characteristic size of a drainage network and its contributing basin surface. Figure 4 show that the watershed follows the Horton's law [7] with perfect linear relation of all the orders. However elongation ratio shows the watersheds are attaining mature and old stage topography. The drainage density indicates an expression of the closeness of spacing of channels, hence provides quantitative measure of average length of stream channel area of the whole watershed. The drainage density is estimated to be 2.41 , which is a very useful index of catchment characteristics and it affects the magnitude of stream flow from a catchment. According to [8] the low drainage density is a characteristic of regions of highly resistant or highly permeable surface and low relief. High drainage density is found in 

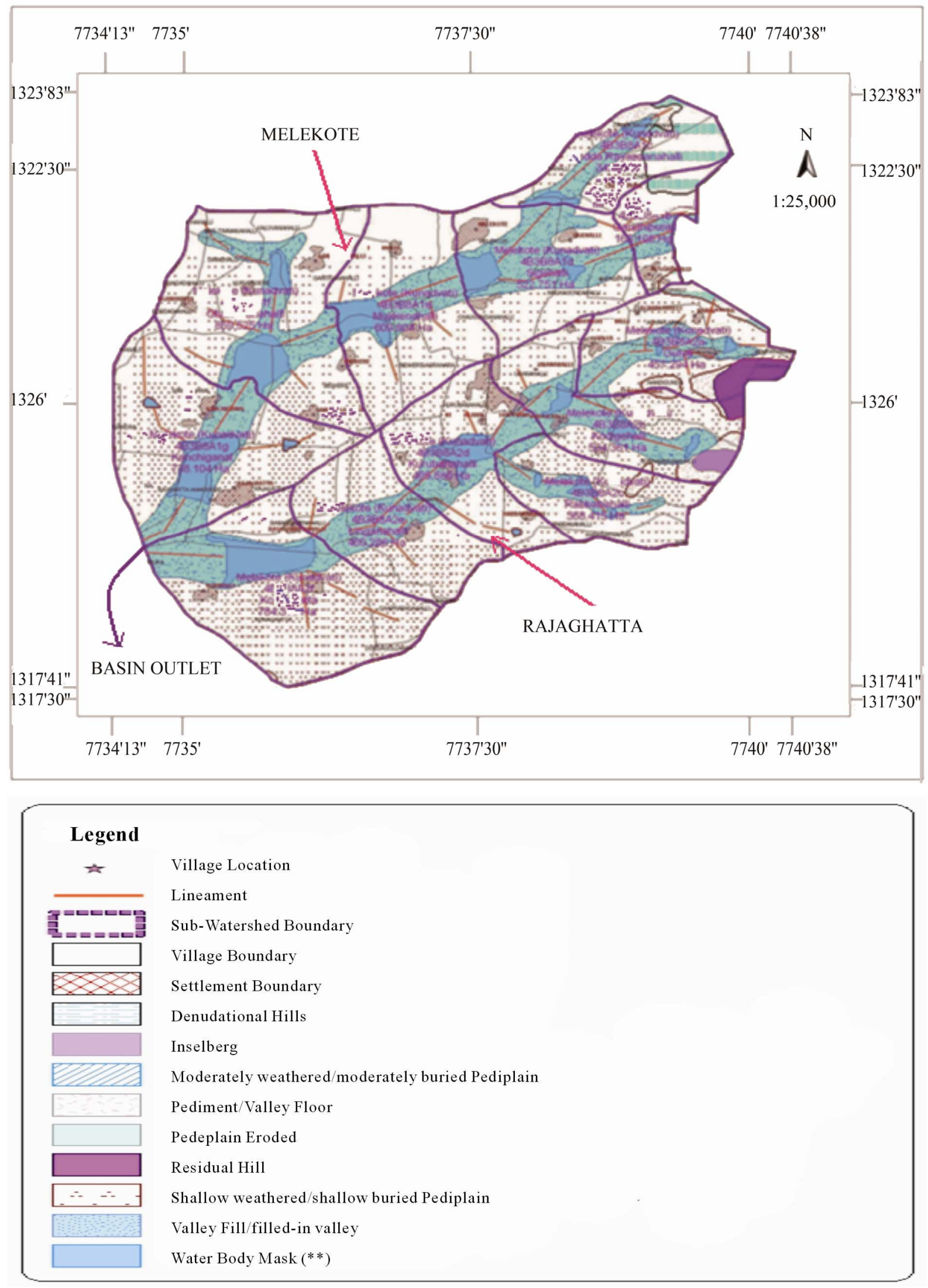

Figure 2. Water bodies and lineaments. 


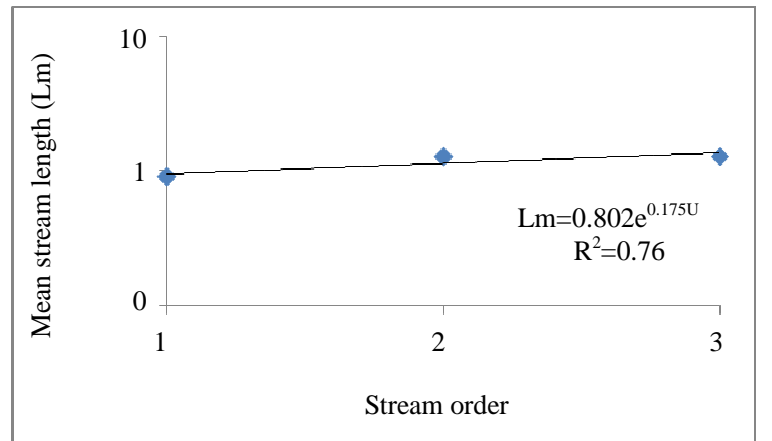

Figure 3. Regression of log. of mean stream length V/s stream order.

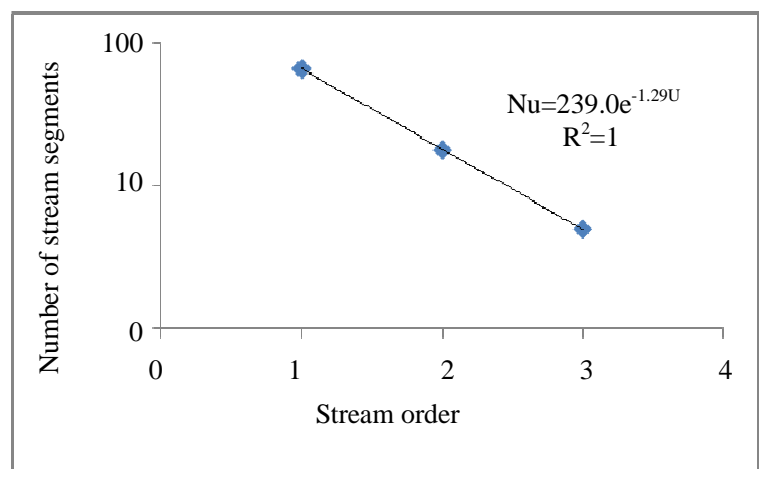

Figure 4. Regression of log. of number stream segments/s stream order.

Table 1. Chracterstics of two watersheds representing different environs.

\begin{tabular}{cc}
\hline Basin Characterstics & Values \\
\hline Area of watershed (sq km) & 95.83 \\
Perimeter of watershed (km) & 43.62 \\
Width of watershed (km) & 11.34 \\
Highest stream order & 3 \\
Cumulative length of stream (km) & 89.06 \\
Bifurcation ratio & 3.66 \\
Watershed shape factor & 2.43 \\
Form factor & 0.74 \\
Compactness coefficient & 0.4 \\
Circularity ratio & 2.5 \\
Elongation ratio & 0.5 \\
Drainage density (km/sq km) & 2.41 \\
Constant of channel maintenance & 0.41 \\
(km/sq km) & 0.92 \\
Stream frequency & 0.75 \\
Watershed relief & 0.049 \\
Relative relief & 0.017 \\
Relief ratio & 1.80 \\
Ruggedness number &
\end{tabular}

regions of weak or impermeable subsurface materials, sparse vegetation and mountainous relief. In the present case, the drainage density is (2.41) indicating average permeability in the watershed. [9] state that in areas of low relief drainage density may be more indicative of permeability of surface material and therefore, could be used as a criterion for the selection of suitable sites for deep wells. Drainage density also influences run-off pattern and thereby infiltration capacity of the rock material. The constant of channel maintenance depends on the rock type, permeability, climate, vegetation cover and relief [10]. It has been observed that constant will be extremely low in an area of close dissection. The value 0.41 sq. $\mathrm{km} / \mathrm{km}$ was obtained for constant of channel maintenance for watersheds. This shows that the watersheds are controlled by the presence of lineaments. The stream discharge is influenced by the shape of the basin and the surface runoff. It has been found that a long narrow drainage basin with high bifurcation ratios would be expected to have attenuated flood discharge period but on the other hand the round basin with low bifurcation ratio would be expected to have sharp peak flood discharge [10] study circulatory ratio, elongation ratio, form factor and compactness coefficient have been examined. The value of circularity ratio of 2.5 exhibits catchments maturity and old stage topography.

\section{Water Quality}

Water quality degradation can also cause scarcity of good quality water. Freshwater bodies also have quality problems due to pollution stemming from expanding urban activities industrial application and improper agricultural uses. Conceptually water quality refers to the characteristics of water supply that will determine its suitability for a specific use, i.e., how well the quality meets the need of the user. Groundwater becomes a usable resource when the water bearing formations are permeable enough to yield adequate quantity of good quality water. Compared to surface water, groundwater is relatively free from the effect of surface pollutants and is less susceptible to changes in quality, chemical composition and temperature variations. However its salinity values are relatively higher.

\section{Results and Discussion}

The watershed has a moderate slope of $2.5 \%$ and a relief of $0.75 \mathrm{~m}$ with a drainage pattern varying from dendritic to subdendritic. In view of this watershed is more prone to erosion, and less stable. The lower value of channel maintenance $(0.41 \mathrm{sq} \mathrm{km} / \mathrm{km})$ the watershed indicates the presence of large number of lineaments. Elongation ratio of the watershed is an indicative of the attaining maturity and old age topography. The presence of a large number 
Table 2. Linear characteristics of watersheds.

\begin{tabular}{cccccccc}
\hline Stream Order & $\begin{array}{c}\text { No. of } \\
\text { Segments }\end{array}$ & $\begin{array}{c}\text { Total Length } \\
(\mathrm{km})\end{array}$ & $\begin{array}{c}\text { Bifurcation } \\
\text { Ratio }\end{array}$ & $\begin{array}{c}\text { Mean Length } \\
(\mathrm{km})\end{array}$ & Length Ratio & $\begin{array}{c}\text { Drainage } \\
\text { Density } \\
(\mathrm{km} / \mathrm{sq} \text { km) }\end{array}$ & $\begin{array}{c}\text { Stream } \\
\text { Frequency }\end{array}$ \\
\hline 1 & 66 & 59.63 & & 0.9034 & & & \\
2 & 18 & 23.01 & 3.6 & 1.278 & 0.700 & 0.91 & 0.990 \\
3 & 5 & 6.42 & 3.6 & 1.284 & & \\
Total & 89 & 89.06 & & & & \\
\hline
\end{tabular}

of lineament sand catchments attribute to impermeable subsurface. The watershed has a large number of small water bodies. The minimum and maximum concentrations of various constituents in the water samples collected from the dug wells and bore wells during different seasons in the study area have been presented in Table 3. Observed ranges of different constituents in the well water indicate variations. Most of the dug well water $\mathrm{pH}$ values observed are less than the prescribed range of 6.5 8.5 for drinking water purpose. High level of dissolved solids, are reflected from the conductivity values in the watershed. Concentration of $\mathrm{NO}_{3}^{-} \mathrm{N}$ above $3 \mathrm{mg} / \mathrm{l}$ (nitrate: $13.5 \mathrm{mg} / \mathrm{l}$ ) in ground water are representative of orthopogenic sources. High level of nitrate content has been observed in some of the observation well waters indicating the possibility of domestic/agricultural wastes reaching the water sources. Over $75 \%$ of the observation wells in the catchments, especially the dug wells showed significant level of nitrate during monsoon and post monsoon periods indicating the possibility of migration of nitrates to the wells during rainy season. This is from field observations, such as poor maintenance of the well surroundings, lack of proper drainage system and poor sanitary conditions prevailing around the wells. The iron concentrations in about $80 \%$ of the dug well-waters especially during pre-monsoon and monsoon seasons are observed to be above the maximum permissible level $(1.0 \mathrm{mg} / \mathrm{l})$, irrespective of the seasons. The common problems faced by the people due to high iron concentrations are iron taste, staining of pipes, vessels and clothes, and cooked food getting spoiled fast. Water with conductivity range between 750 to $2250 \mu$ mhos/cm is successfully used for irrigation with satisfactory crop growth, coupled with good management and favorable drainage conditions. The conductivity levels in the well water of watershed were found within the recommended range, with a maximum recorded value of $1700 \mu \mathrm{mhos} / \mathrm{cm}$ during summer season. However, water with low conductivity need not be always suitable for irrigation, since the presence of significant concentrations of specific ions such as sodium, magnesium, chloride, bicarbonates, and sulphate do produce toxicity and lead to crop hazards. The evaluation of sodium adsorption ratio (SAR) and residual sodium carbonate (RSC) indices will help in revealing the safety of water from alkalinity hazard. The SAR values of the well waters in the study area range from 9.54 to 48.6 and the RSC level ranges from 0.125 to 0.35 indicating suitability for irrigation.

\section{Assessments of Water Quality and Types}

The piper tri-linear diagram is an effective tool in segregating the analyzed data for critical study with respect to sources of the dissolved constituents in water, modifications in the quality of water as it passes through an area, and related geochemical problems. The analyses of water samples include physical and chemical tests besides the nature and magnitude of the impurities present and suitability of water for different purposes [11]. Figure 5 represent the tri-linear plot will show the essential chemical characteristics of water according to the relative concentrations of its constituents. These diagrams reveal the analogies, dissimilarities and different types of waters in the study area. The concept of hydro chemical faces was developed in order to understand and identify the water composition in different classes. In the tri-linear plot at the lower left, the percentage reacting values of three cations $\left(\mathrm{Ca}^{2+}, \mathrm{Mg}^{2+}\right.$ and $\left.\mathrm{Na}^{+}+\mathrm{K}^{+}\right)$are plotted as a single point according to conventional tri-linear coordinates. The three anion groups $\left(\mathrm{Cl}^{-}, \mathrm{SO}_{4}^{-}\right.$and $\left.\mathrm{HCO}_{3}^{-}\right)$are plotted likewise in the triangular field at the lower right. Thus, two points on the diagram, one in each of the two triangular fields, indicate the relative concentrations of the several dissolved constituents present in groundwater. The central diamond-shaped field is used to show the overall chemical characteristics of ground water by a third single-point, which is at the intersection of the rays projected from the two plots of the cation-anion pairs that correspond to the four vertices of the field. These water sample test wells more or less represent the entire subwatersheds of Melekote and Rajaghatta. Ground water samples were analysed for $\mathrm{pH}$, EC, Phosphate $\left(\mathrm{PO}_{4}^{3-}\right)$, Iron $\left(\mathrm{Fe}^{3+}\right)$, Sodium $\left(\mathrm{Na}^{+}\right)$, Potassium $\left(\mathrm{K}^{+}\right)$, Calcium $\left(\mathrm{Ca}^{2+}\right)$ and Magnesium $\left(\mathrm{Mg}^{2+}\right)$, Chloride $\left(\mathrm{Cl}^{-}\right)$, fluoride $\left(\mathrm{F}^{-}\right)$, sulphate $\left(\mathrm{SO}_{4}^{2-}\right)$, and nitrate $\left(\mathrm{NO}_{3}^{-}\right)$as per the standard analytical procedure. 


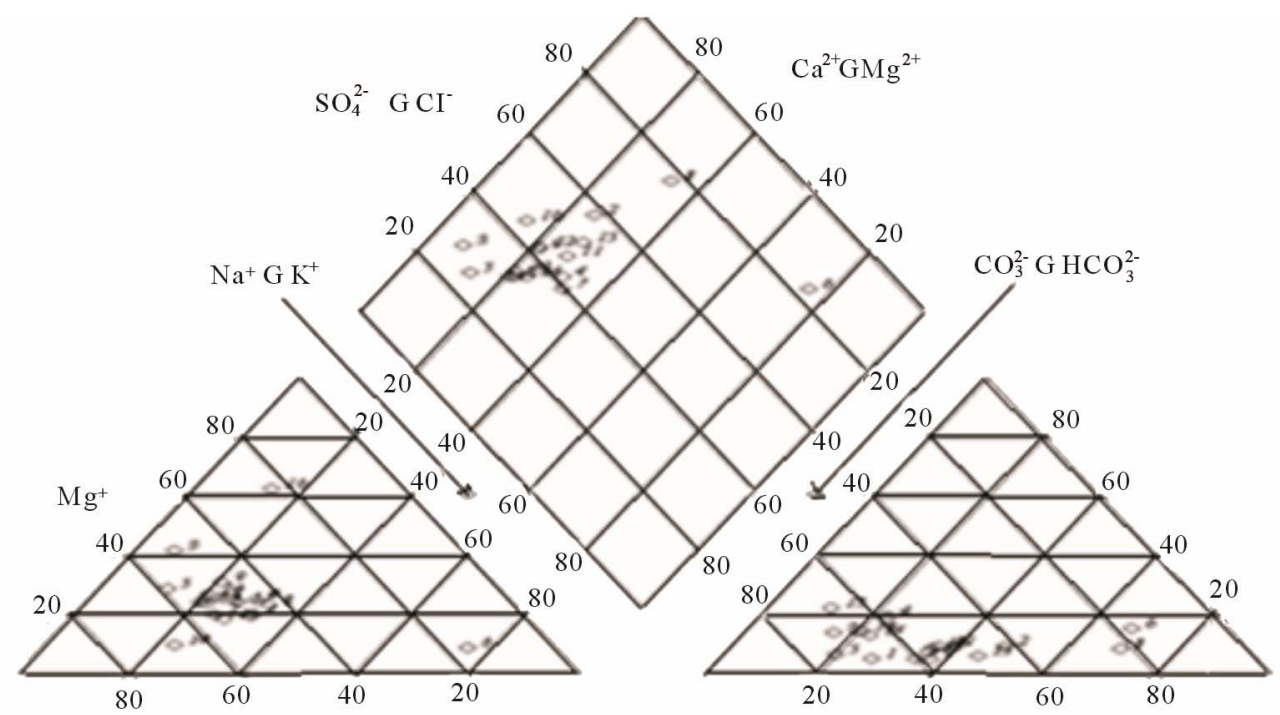

Figure 5. Piper tri-linear diagram showing the chemical composition of ground water during post monsoon.

Table 3. Hydro-chemical assessment.

\begin{tabular}{|c|c|c|c|c|c|c|}
\hline \multirow{3}{*}{ Physico-Charasterestics } & \multicolumn{6}{|c|}{ Minimum-Maximum } \\
\hline & \multicolumn{3}{|c|}{ Bore Well } & \multicolumn{3}{|c|}{ Dug Well } \\
\hline & Pre-Monsoon & Monsoon & Post Monsoon & Pre-Monsoon & Monsoon & Post Monsoon \\
\hline $\mathrm{pH}$ & $7.6-8.41$ & $6.7-8.1$ & $7.0-7.3$ & 7.3 & 7.4 & 6.8 \\
\hline Electrical conductivity (EC) & $1034-431$ & $1700-247$ & $1034-161$ & 334 & 332 & 230 \\
\hline Total alkalinity (TA) & $316-36$ & $232-34$ & $316-36$ & 60 & 60 & 32 \\
\hline Total hardness (TH) & $383-61$ & $372-28$ & $383-61.6$ & 80 & 80 & 72 \\
\hline Total dissolved solids (TDS) & $104-664$ & $178-1200$ & $260-746$ & 512 & 512 & 150 \\
\hline Chloride (Cl) & $121-11$ & $143-5$ & $121.7-11.6$ & 28.7 & 28.7 & 34.9 \\
\hline Fluoride (F) & $0.74-0.11$ & $0.3-0.1$ & $0.5-0.04$ & 0.3 & 0.3 & BDL \\
\hline Sulphate $\left(\mathrm{SO}_{4}\right)$ & $46.8-1.8$ & $63-7.6$ & $59-11.5$ & 22.4 & 22.4 & 11.1 \\
\hline Nitrate $\left(\mathrm{NO}_{3}\right)$ & $62.6-3.5$ & $33.2-3.2$ & $21.3-3$ & 19.8 & 19.8 & 18.9 \\
\hline Iron (Fe) & $0.14-0.06$ & BDL & $0.1-0.05$ & 0.8 & 0.8 & BDL \\
\hline Sodium (Na) & $62.16-14.6$ & $58-12$ & $72-9$ & 21 & 21 & 25 \\
\hline Potassium (K) & $6.7-0.7$ & $13-4$ & $16-1$ & 12 & 12 & BDL \\
\hline Calcium (Ca) & $113.6-12.2$ & $133-8.8$ & $82.5-11.2$ & 16 & 16 & 19.2 \\
\hline Magnesium (Mg) & $22.9-1.5$ & $30.6-1.4$ & $48.6-3.8$ & 9.7 & 9.7 & 5.8 \\
\hline
\end{tabular}

NB: All values are expressed in mg/l except $\mathrm{pH}$ and $\mathrm{EC}$, $\mathrm{pH}$ in $\mathrm{pH}$ units;EC in micromhos/cm at $25^{\circ} \mathrm{C}$; BDL: Below detectable level.

\section{Conclusion}

The ground water quality in the watershed region is fairly good and potable. The variation of chemical concentration possibility of pollutants from domestic sewage entering the sub-surface, leads to pollution. Inadequate drainage systems and ill maintenance of the well sur- roundings are found to be the reasons for contamination. The results of the chemical analyses of water samples reveal that there are no abnormalities in them. The two sub-watersheds are unexplored water stressed region with regard to water resources. The suitability of water for irrigation is evaluated based on SAR, \% Na, RSC and salinity hazards. All samples in the watersheds reveal 
suitable range of constituents for irrigation.

\section{REFERENCES}

[1] I. Zavoinu, "Morphometry of Drainage Basins,” Elsevier, Amstedam, 1985, p. 238

[2] R. J. Chorley, "The Drainage Basin as the Fundamental Geomorphic Units,” Water, Earth and Man: A Synthesis of Hydrology, Geomorphology and Socio-Economic Geography, Methuen and Co Ltd., London, 1969, p. 588.

[3] M. Evenari, “The Nagev: The Challenge of a Desert," Oxford University Press, Oxford, 1971.

[4] A. Agarwal and S. Narain, "Rise and fall Water Harvesting,” Dying Wisdom, 4th Report, Centre for Science and Environment, New Delhi, 1997, pp. 269-312.

[5] J. Krishnamurthy, G. Srinivas, V. Jayaraman and M. G. Chandrashekar, "Influence of Rock Types and Structures in the Development of a Drainage Networks in Typical Hardrock Terrain,” ITC Journal, Vol. 3, No. 4, 1996, pp. 252-259.

[6] A. N. Strahler, "Quantitive Analysis of Watershed Geomorphology," Transaction of the American Geophysical Union, Vol. 38, No. 6, 1957, pp. 913-920. doi:10.1029/TR038i006p00913

[7] C. R. Horton, "Erosional Development of Streams and Their Drainage Basins: Hydrophysical Approach to Quantitative Morphology," Geological Society of America Bulletin, Vol. 56, No. 3, 1945, pp. 275-370. doi:10.1130/0016-7606(1945)56[275:EDOSAT]2.0.CO;2

[8] A. N. Strahler, "Quantitive Geomorphology of Drainage Basin and Channel Networks,” In: V. T. Chow, Ed., Hand Book of Applied Hydrology, McGraw Hill Book Co., New York, 1964, pp. 439-476.

[9] B. B. S. and R. P. Gupta, "Applied Hydrogeology of Fractured Rocks,” Kluwer Academic Publishers, New
York, 1999.

[10] R. K. Jaiswal, J. Krishnamurthy, S. Mukherjee and M. Sameena, "Role of Landform and Topographyin the Development of Drainage Networks," Hydrology Journal, Vol. 30, No. 1-2, 2007, pp. 1-13.

[11] J. D. Hem, "Study and Interpretation of the Chemical Characteristics of Natural Water," U S Geol. Water Supply Paper 2254, Scientific Publishers, Jodhpur, 1991.

[12] A. M. Piper, "A Graphic Procedure in the Geochemical Interpretation of Water Analysis," Groundwater Note No. 12, US Geological Survey, 1953.

[13] A. V. Shivapur, M. Ish, B. K. Purandara and I. T. Shirkol, "Comparative Study on Bennihalla and Bedthi Catchment through the Analysis of Their Morphology, Land Form and Topographic Characterstics," Society for Hydraulics Journal of Hydraulic Engineering, Vol. 16, No. 1, 2010, pp. 69-78.

[14] C. Sadashivaiah, E. R. Ramakrishnaiah and G. Ranganna, "Hydrochemical Analysis and Evaluation of Groundwater Quality in Tumkur Taluk,” International Journal of Environmental Research and Public Health, Vol. 5, No. 3, 2008, pp. 158-164. doi:10.3390/ijerph5030158

[15] A. Shahul Hameed and N. B. Narashimhaprasad, "Hydro-Chemical Assement and Ground Water Recharge Mechanissm in the Humid Tropics," Jouranl of Environmental Science and Engineering, Vol. 50, No. 4, 2008, pp. 263-270.

[16] B. K. Handa, "Natural Waters, Their Geochemistry Pollution and Treatment," 2nd Tech Manual, Central Ground Water Board, New Delhi, 1975.

[17] Anon, "Karnataka at a Glance," 8th Report, Directorate of Economics and Stastics, Government of Karnataka, Bangalore, 2010. 